DOI:

\title{
THE MYTH OF RUSSIAN STUPIDITY IN RFL LESSONS
}

\author{
Natalia V. Roitberg \\ PhD in Philology, lecturer \\ University of Haifa \\ (Haifa, Israel) \\ e-mail: roitbergnatalia@gmail.com
}

\begin{abstract}
This study addresses the use of folklore materials among advanced and intermediate-level students of Russian. Special attention is devoted to the Russian folk character Ivan the Fool, the myth of Russian stupidity, and mechanisms by which the theme of foolishness presented in Russian folklore and literature. The paper focuses on the reading Russian fairy folk tales of Ivan the Fool (Leo Tolstoy's "The Tale of Ivan the Fool and his two brothers" and the tale "Before the Cock Crows Thrice" by Vasily Shukshin) and the interpreting Russian proverbs and sayings about fools which are shown as conceptions of the myth of Russian stupidity. It was determined that the use of Russian folktales and proverbs as curriculum materials have a great educational significance, linguistic importance on Russian language teaching, as well as on the Russian language acquisition. Furthermore, folklore materials are considered efficient tools for foreign students' deeper insight into Russian mentality and folk lore.
\end{abstract}

Keywords: Russian as a foreign language lesson (RFL lesson), folklore materials, fairy tales, Ivan the Fool, the myth of Russian stupidity

\section{МИФ О РУССКОЙ ГЛУПОСТИ НА УРОКАХ РКИ}

\author{
Наталья Владимировна Ройтберг \\ Кандидат филологических наук, лектор \\ Хайфский Университет \\ (Хайфа, Израиль) \\ e-mail: roitbergnatalia@gmail.com
}

\begin{abstract}
Аннотация. В статье рассматривается использование материалов устного народного творчества на уроках русского языка как иностранного студентам среднего и продвинутого уровней. Отдельное внимание уделено образу Ивана-дурака, мифу о русской глупости и способам репрезентации темы «простофильства» в русском фольклоре и литературе. В статье сделан акцент на анализе русских народных сказок об Иване-дураке («Сказка об Иване-дураке и его двух братьях» Льва Толстого и «До третьих петухов» Василия Шукшина) и интерпретации русских народных пословиц о дураках. Многие из русских поговорок и выражений показаны как концепции мифа о русской глупости. По мнению автора, использование русских народных сказок и пословиц как учебного материала имеет огромное образовательное значение и лингвистическую ценность при обучении и усвоении русского языка иностранными студентами, а также значительно расширяет их возможность ознакомления с русской ментальностью и фольклором.
\end{abstract}

Ключевые слова: урок русского языка как иностранного (урок РКИ), материалы фольклора, волшебные сказки, Иван-дурак, миф о русской глупости 


\section{INTRODUCTION}

Russian culture is rooted in hundreds of years of traditions, customs, beliefs, folktales which passed down from generation to generation. Many customs and practices still exist in Russia today. The main aim of this paper is to present the possible and efficient ways and techniques to use different folklore materials in Russian as a foreign language (RFL) lesson for advanced and intermediate level students. The additional purpose is to trace the literary and cultural mechanisms by which the theme of stuck hero (Ivan the Fool) developed in Russia from the early nineteen century (the traditional fairy folkloric tales for children) through the classical period ( "Ivan the Fool and his Two Brothers" (1886) a literary fairy tale by Leo Tolstoy) to our days (contemporary literary works about Ivan the Fool - for instance, Vasily Shukshin's fairy tale "Before the Cock Crows Thrice" (1975)). In this way one could illustrate to students an evaluation of Ivan the Fool character.

Undoubtedly, folkloric fairy tales of the fool and proverbs about stupidity played a leading role in this process. At the same time, however, it is necessary to pose questions about the relationship between folkloric tradition and the contemporary context in which the conception of foolishness is actualized. Naturally, understanding of Russian both traditional and modern culture is impossible without a deep insight into Russian culture and Russian folklore. The latter represents the Russian identity through folk songs, proverbs, and so on. One of the most ancient folk genres is the tale.

A folktale (or folk tale) is a wonderful phenomenon of Russian national culture. The folk tale is a typically short magical story that usually features folkloric fantasy characters. Folktales are of three kinds: animal tales, tales of everyday life, and magic (fairy) tales. The use of latter in RFL teaching will be considered in this paper. I prefer to use the term "fairy tale" as more common one.

Russian fairy tales share many plots with European, American, Asian tales, legends, and myths. Since, foreign students can easily guess that certain Russian folk heroes and Russian fairy tales' plots correspond to the ones of their own native culture. It is not surprising, then, that fairy tales are a good source for motivation in RFL learning that help increase students' interest in values across cultures and provide them with a cross-cultural experience.

Fairy tales may be used to expose students to the essential cultural and ethical national elements, codes and key concepts of both the target culture and the native one: "From the earliest stage of storytelling, oral tales and their manifold retellings have served [...] to educate audiences about valuable life lessons and universal truths" (Schwabe, 3). Teachers can use these qualities of folktales to engage students in RFL learning and encourage respect for Russian culture.

Use of folk fairy tales offers students an excellent opportunity also to involve with authentic cultural texts of the Russian folkloric tradition yet enrich themselves by understanding better and deeper the socio-cultural reality of Russia. For many investigators, there is a strong tendency to assume that use of folktales "can act as a bridge for arousing cultural awareness" (Ajibola, 248), and is a "valuable rich cultural and linguistic recourse to teach a foreign language" (Nhung, 23) that should be integrated in foreign language teaching.

\section{REVIEW OF LITERATURE}


Some of scholars analyze certain methodological techniques of the folk tales text use for the linguistic and cultural purposes, emphasizing their educational significance and value (Lwin, 2015; Merrill, 2016; Prastiwi, 2015; Taylor, 2006). As for using Russian fairy tales in RFL teaching, many researches point out its effectiveness (Arysheva, 2014; Barsukova-Sergeieva, 2013; Fliantikova, 2016; Shylko, 2012). Other investigators stress fairy tales' role in representing Russian mentality (Bordovskaya, 2005) as well as the cultural and linguistic importance of fairy tale in RFL lessons (Igoshina, 2003; Trygub, 2006). Recent new works on foreign-language methodology deal with cultural potential of screened Russian folk fairy tales and analyze certain ways of their using (Abdarahmanova, 2010; Krivonos, 2010; Matveenko, 2013). Importantly, some researchers emphasize folk hero fool's great role in shaping national identity of Russia and its great influence on perception of Russia in contemporary world (Vorkachev, 2017; Zaharenko, 2004; Trubetskoi, 1995).

Therefore, using fairy folktale in RFL lesson gives to foreign students a chance to promote understanding of Russian traditional culture and have a deeper insight into Russian rituals and folk belief. It is impossible to involve students in Russian cultural context and - more widely - in Russian worldview without pointing out the special features of Russian national character and mentality. Sic, I would offer literary folk stories (Tolstoy's and Shukshin's fairy tales of Ivan the Fool) and numerous proverbs and sayings about Ivan the Fool for RFL class.

\section{RESULTS AND DISCUSSIONS}

The following issues will be highlight below: how Ivan the Fool represents the "Russian fool" of our time; how this stock character (Ivan the Fool; Ivan Durak; Ivanoushka the Simpleton) has changed over time (folklore - the classical period - the Soviet epoch); how Ivan the Fool is represented in folkloric tradition and in modern literature; how Russian proverbs and common sayings about foolishness provide a deeper understanding of the phenomena of Russian stupidity and could help decode the world of Russian fairy tale.

Fairy-tale heroes largely divide into two constrastive types: "the handsome, desirable prince [...] or the irresponsible youngest of three sons, often signally named Ivan the Fool (Ivan Durachok), who lolls indolently on the stove" (Goscilo, 2005). The latter one merits special attention because emerges as both naive looser and lucky winner.

Ivan the Fool is one of the folklore favorite heroes, the most popular, yet paradoxical folktale character. Generations of Russian children grew up reading folk fairy tales of "Ivan-durak".

It could be argued, that Ivan the Fool created what could be called the myths of Russian stupidity, myths that were developed and canonized not in fiction but in folklore. Indeed, it would be fair to say that Ivan the Fool became the source of a certain number of myths of Russian foolishness. The most popular Russian tales of the Fool are "Emelya the Simpleton", "The Tale of Bova the King's Son", "Ivan the Fool", and "The Three Kingdoms". Each of them is an excellent example of how one can provide students material to dissect the key concepts of Russian way of thinking: "Ivan the Fool for the Russian culture is the "People's favorite character" (Trubetskoi), he is "the all-Russian national hero" (Semyon Frank), and making a fool of himself, the perception of himself as a silly, stupid man is "the self-consciousness of the Russian people" (Andrey Platonov )" (Vorkachov, 19). 
Ivan the Fool (Russian: Иван-дурак, Ivan Durak) is a stock character of lucky fool. He is a very simple-minded. It often seems, that his deeds are senseless, his actions are impractical. However, Ivan the Fool is rarely the fool, he is merely perceived as such. In his investigation of Russian folk belief, Sinyavsky (Sinyavsky, 38) argues: "The Fool's luck changes not because he is wiser, but because he is still doing the most idiotic things. Idiotic behavior turns out to be an indispensable condition of happiness - the condition for the coming of divine or magic powers".

One would see Ivan the Fool simply as a symbol of national stupidity and laziness, since he is often portrayed as lazy or foolish. However, using cleverness and tricks he usually emerges winner. One should mention that Ivan the Fool is associated with the hero-fools of the other countries' tales: "the folktale Fool is known and loved not only by the Russians. He is international hero" (Sinyavsky, 39). Indeed, Russian stock character Ivan the Fool corresponds with the German Hans Dump (Hänsel; Stupid Michel), English John (or Jack), Italian Juvadi, Peruonto, and Peter the Fool, Polish Jasio, Greek Halfman, Jewish Schlumiel and Schlimazel, Danish Lazy Lars, and many others. One of the possible literary (not folkloric) texts that can be analyzed on RFL lessons is an author's tale about Ivan the Fool. It exists in several variants: for example, Maxim Gorky`s "Pro Ivanushku-Durachka", Vagner's "Dva Ivana", and so on. I would refer to Leo Tolstoy's the tale of Ivan the Fool.

1. Tolstoy's tale of Ivan the Fool. The story (the full title is "The Tale of Ivan the Fool and his two brothers, Semyon the Soldier and Taras the Big-Belly, and of his sister Malyana the Mute, and of the Old Devil and the three Imps") describes the struggle of three brothers (Ivan the Fool and his two brothers) and the Old Devil. Events described are quite trivial: Semyon and Taras have taken from Ivan the Fool part of the inheritance he received from their father.

However, there are some spirits characters (the Old Devil and the Three Imps) and magic motifs (Imps disappearance: "No sooner had Ivan said "God" than the imp plunged into the earth like a stone into water, and there was nothing to be seen but a hole" (Tolstoy, 108); each imp promice to Ivan grant his wish: "Don't hurt me! - said the imp. - I will do whatever you wish!" "What can you do?" "Anything you wish. You have only to tell me!" (Tolstoy, 107)). Therefore, the story turned into the fairy tale. Ivan the Fool is identified and usually interpreted with the fool in his nickname, abilities, and appearance that are reminiscent of a stupid man (a dirty man dressed in rags; simplicity, naivety, homeless). Sic, when Semyon the Soldier asks his father to give him his share, the father says: "You brought nothing into my house, why should I give you a third part? It would not be fair to Ivan". Semyon has an excellent argument, he replies: "But you know he's a fool". Taras the Big-Belly also comes to his father to take his share. But the old man was unwilling to give Taras anything either, because it would not be fair to Ivan, Taras replied like Semyon: "He's a fool! He cannot marry, no one would have him" (Tolstoy, 104). What about Ivan the Fool? Every time he says: "Well, why not? Let him have it". Moreover, when Semyon and Taras had lost their estate and had come home to live with their father and Ivan, their wives both objected to Ivan's smell and wanted him to go out: "You don't smell good, Ivan. You'd better go eat in the entry". And this time he too said the same: "Well, why not?". (Tolstoy, 113). However, finally, despite of all the troubles, Ivan became the triumphant and Tsar: "Ivan steel lives to this day, and people flock to his kingdom to live". Moreover, he is still generous and friendly to everybody: "And whenever anyone comes and says: "Feed us," Ivan says: "Well, why not? Stay with us and welcome" (Tolstoy, 137). 
Have students to discuss answers to the following questions: What interesting things probably you didn't know before - about Russian people of that time, their fears and hopes, have you learned? What moral lessons does the story of the fool teach? What can you say about the major characters in these fairy tales? What do folk tales teach us about Russian culture? What elements have been identified as typically 'Russian'? The topics of discussion predominantly will focus on characters the tale and their specific features. In conclusion, one can deal with exposition and resolution of Ivan the Fool character specific role in this tale.

2. Vasily Shukshin's «Before the Cock Crows Thrice». In general terms, one could say that literary works of Ivan the Fool used the myths of foolishness that folklore tradition had proposed. It is likely that the Soviet Russian authors had the literary sophistication to use Ivan the Fool folk tales consciously ignoring the formal ambiguity inherent in the naive character.

I'm not suggesting that modern writers necessarily had to modify large portions of their works to conform to the folklore myths. Nevertheless, they organized and interpreted their plots and heroes in accordance with patterns drawn from folklore tradition. Therefore, Ivan the Fool tales turned out to be coloured by the books that are familiar to most readers.

It is hard to determine whether the patterns of foolishness proposed by folklore reflected preexisiting cultural myth or whether they created them. Most probably, both processes were at work. At the very least, the modern authors canonized the myths relating to foolish character in literary form.

There is a several fairy tales and verses in contemporary Russian literature that represent Ivan the Fool plot, they are following: Irina Batyi's "Chego pozhelat' Duraku" (Batyi, 2008); N.A. Sulima's "Skazka o Ivane Zareviche I ob odnom iz iego podvigov" (Sulima, 2008), Vasily Shukshin's «Before the Cock Crows Thrice» (Shukshin, 2005), and so on. The latter one is considered to be the most odious and important contemporary interpretation of Ivan the Fool story.

Shukshin's story (the full title is "A Tale about Iven the Fool, how he Traveled Beyond the Thrice-Ninth Kingdom to Acquire Some Wits and Wisdom”) belongs to fairy-tale Soviet discourse which is dual, yet paradoxical: "The paradox of fairy-tale discourse within Soviet cultural identity may be defined by its dual function: it simultaneously shapes the luminiscent anima an the dark aspects of the Soviet collective unconscious, its shadow [...] The only difference between te Soviet fairy tale and the traditional tale for children is the fact that the Soviet fairy tale focuses on social life and social conflicts rather than on inner life and the mental processes of an individual" (Lipovetsky, 2005).

At first glance, the focus on Ivan's deeds and destiny seems contradictory in a fairy-tale Soviet discourse that embraces moral values and ideals of communist society. But close reading reveals the satiric effect of this focus. The major target of Shukshin was to show the extent to which the myth of the foolish character permeated Russian thinking. As Lipovetsky notes, "The satiric power of Shukshin's fairy tale may be appreciated fully only if one recognizes in its narrative the fairy-tale master plot of the "simple man's" maturation adopted by socialist realist aesthetics...Ivan's "maturation" is absurd, since it constantly requires his humilitation and leads only to a greater degree of humilitation" (Lipovetsky, 2005).

Therefore, the core concept of the story was to show usefullness and absurdity of the confused reality of the Soviet period. The communist utopia, inherent for the former, serves for writers like Shukshin as a basis "for the anti-totalitarian vector of the fairy-tale tradition" (Lipovetsky, 2005). 
In fact, we are presented with a new version of the plot, familiar to readers from the opening pages of Tolstoy's Ivan the Fool or folk fairy tale of Ivan the Fool. Shukshin's Ivan story also merged with that of the traditional folklore's Ivan the Fool. The similarity is strengthened through the composition and system of main heroes - these ones are typically folk heroes, such as: Baba Yaga, Gorynych the Dragon, and Princess Neverlaugh. In contradistinction to fairy folk tales about Ivan the Fool, in Shukshin's story there are also such heroes as Devils and Wise Man.

Shukshin's Ivanushka lives in a library with a lot of other characters. One of them Turgenev`s poor Liza - ask to send Ivan the Fool to the Wise Man for a sertificate of intelligence. Interestingly, that from Ivan`s conversation with Baba Yaga it is clear that Ivan doesn`t fool at all he is "just guileless": "I mean, are you a complete fool or did they call you a fool on the spur of the moment?[...] Surely you don't think you're foolish, do you?" "Ive never thought it!" said Ivan angrily. "How could I think I was a fool?" (Shukshin, 2005).

Moreover, in his conversation with Wise Man's secretary called Milka Ivan convincingly shows that he is even more clever than others: "I see. You think I'm a brainless idiot. That I go about a clog. You called me stupid. You may as well know that I'm cleverer than all of you. I'm deeper, more of a folk hero. I radiate hope [...] I'm the essence of the Russian soul and you're nothing” (Shukshin, 2005). Unlike Tolstoiy's Ivan, Ivanoushka is a failer: his opponents intenionally humiliate him, they "either want to use him as a free labour force, or, worse, to entertain themselves at his expence", moreover they abuse and objectify Ivan's song and dance, something that he values "very highly" (Lipovetsky, 2005). Shukshin's Ivan doesn't afraid of death and every time sing something. For inctance, when Yaga and his bodyguardes began to shovel Ivan into the stove, he began to sing:

I shaved you in the garden, among the hollyhocks,

And in return you gave to me a pair of shoes and socks.

Toora-loora-loora, toora-loora-lay.

Fire doesn't burn me, so I needn’t be afraid! (Shukshin, 2005).

Like a typical anti-hero, Ivan is very vulgar and extremly rude sometimes, get angry, doesn 't behave himself. That's part of reason why his opponents call him "a shizo", "a fruit" which sometimes consciously get up to tricks and other times he "doesn't know what he's doing". For example, he promises to devil to drag them "across [...] bumpy ground" and kick their bottles. Interestingly, this Shukshin's story was received by many students not as a literary work, but instead as a social and political manifest.

After reading the text students may be asked to compare Leo Tolstoy's the tale of Ivan the Fool with Shukshin's story and discuss similarities and differences between them. For example, the similarities are the following ones: both Tolstoy's Ivan and Shukshin's Ivanoushka struggle with devils/dumps; both should leave home to acquire something, and so on; and the differences are the following ones: only in Shukshin's story Ivan sings folk songs and dance folk dances, yet he encounter characteres from other tales (Princess Neverlaugh) and literary works (he even lives in a library with a lot of other characters); and so on. Have students to discuss whether is it possible to distinguish clearly the difference between Tolstoy`s Ivan, Shukshin's Ivanushka, and the folkloric Ivashko the Stove Sitter. It could be argued that the similarities as well as differences the students have noted between folk tale and literary works of Tolstoy and Shukshin are not accidental, but the result of the fact that whereas both describe the realities of Russian life, they describe the different 
time periods. Have students to discuss answers to the following questions: What interesting things probably you didn't know before - about Russian people of Soviet period, their fears and hopes, have you learned? What moral lessons does the story of the fool teach? What can you say about the major characters in Shukshin's fairy tale? What do folk tales teach us about Russian Soviet culture? What elements have been identified as typically 'Soviet'? The topics of discussion predominantly will focus on characters the tale and their specific features.

The possible additional questions may be the following ones: What do you think would the heroes of these tales do if they found themselves in the modern world? Why do you think so? In conclusion, one can deal with exposition and resolution of Ivan the Fool character specific role in Russian Soviet literature, mentality and way of thinking.

3. Russian proverbs about fools. As mentioned above, Ivan the Fool is one of the most popular folk character. The very Ivan's nickname - the Fool - is remarkable and provides the essence.

It is not surprised then, that in Russia there are a lot of proverbs and sayings refer to foolishness and stupidity. Such topics as Russian proverbs and sayings about foolishness could be analyzed and observed in the framework of the RFL course.

Characteristically, there are two Russian sayings are significant, because they reflect the Russian people's common attitudes toward stupidity. The first saying is "Russia has two problems fools and bad roads", and the second one is "There's no law written for fools" (Dal', 2006). Notably, the latter has a continuation: "If there's a law written, it hasn't been read; and if it's been read, it wasn't understood; and if it was understood, it was misinterpreted".

Additionally, there are some proverbs that also refer to the fool:

Дурака́ учи́ть - что горбатого лечить (“То teach a fool is the same as treating a dead man');

Дурако́в не се́ют, не жнут, са́ми родя́тся (“There's a sucker born every minute”);

Пья́ный проспи́тся, дура́к - никогда́ (Literal: “The drunken will sleep it over, the fool never"). Some of these idioms and proverbs point out to the close connection between the fool and the Lord: "God loves a fool"; yet the fool's unfathomable luckiness and uniqueness:

"Fools have all the luck";

"A fool may throw into a well a stone which a hundred wise men cannot pull out" (the proverb corresponds with the help of magic andlor higher power mentioned above).

That's part of reason why some sayings point out to the wisdom of the fool:

Иной раз и дурак молвит слово в лад (“A fool must now and then be right by chance”);

Временами и дурак умно говорит ("Fools may sometimes speak to the purpose ").

But most of them refer to fool as to silly, stick, yet funny man:

"A fool is not afraid to lose his mind";

"The wise man says "I am looking for truth"; and the fool, "I have found truth";

"It's better to be known as a rascal than a fool", "Force a fool to pray and he'll crack his forehead" (the saying is used to describe a person who has resolved to do something and has overdone it); "A silly head gives legs no rest" (the proverb describes the situation when a person needs to make a second trip because he failed to complete some task the first time);

С дураком шутить опасно ("Never bray at an ass"); Что ни сде́лает дура́к - все он сде́лает не так (Literal: "Whatever a fool makes, he will make it wrong”). 
The teacher can ask students to discuss answers to the questions that refer to the fairy folk tales as well as proverbs about foolishness: What can be learned about Russia through its sayings, idioms and folktales? The teacher can also offer to students to discuss the extent to which Russian folktales and proverbs reveal elements of Russian ethics and culture. Students should use certain examples from the folktales they read and the proverbs they taught to support their statements. As a final assignment, students can be invited to discuss whether they think that people can learn about the everyday life, traditional values, customs and mentality of Russians through Russian folktales and proverbs.

\section{CONCLUSION}

The use of fairy tales (Leo Tolstoy's story “About Ivan the Fool” and Vasily Shukshin's "Before the Cock Crows Thrice") and proverbs illustrates how literary texts can be incorporated in RFL classes. As it appears, there are certain benefits from the use of suitable folklore materials in RFL teaching.

First, using Russian folktales and proverbs as the RFL curriculum materials have a great educational significance and value, linguistic importance in RFL teaching, positive impact on the language acquisition. Second, folktales and proverbs are considered efficient tools for RFL students' deeper insight of Russian mentality. Apparently, folk materials could be helpful in explaining the unique phenomenon of "foolishness" in Russia, yet they provide students with more thorough knowledge and understanding Russian fools' strange behavior and could prompt changing students' attitudes towards Russian fool character ("Ivan Durak"). In fact, students are presented with a new version of the anti-hero, familiar to them from the opening pages of many other different stories (from "Jack Tales" and "Men of Gotham" to Huckleberry Finn and Peter Pan).

As mentioned before, the Fool is an international hero. Therefore, these silly characters could provide the crosscultural connection between Russia and the other countries. While reading and analyzing Russian folk fairy tales and proverbs foreign students do more than simply note similarities between their native culture fairy anti-heroes and that of the Russian culture. They also accept Russian culture's interpretation of anti-hero (Ivan the Fool) as a national hero that became model not for living but for recalling and interpreting the past.

I would suggest that one should distinguish between the view, that throughout 18-19th centuries placed the fool in the folkloric and literary context (folk fairy tales and Leo Tolstoy's the tale of Ivan the Fool), and one that set it throughout 20th century in the sociological context (Vasilii Shukshin's the tale "Before the Cock Crows Thrice"). The fool characters discussed in this paper represent one instance of a much broader socio-cultural and historical context. Both Ivan the Fool folk tale, and numerous sayings and proverbs provide Russia with powerful cultural myth of the Russian stupidity. Indeed, it would not be an exaggeration to say that, to a great extent, this myth defines the cultural and social image of Russia.

It has long been recognized that simpleton fool such as Ivan the Fool played (and continues to play) a much more important social role in Russia than in any Western country. Clearly, one of the primary reasons for this is the peculiarly symbiotic relation between works of literature and Russian history. The latter was full of wars and violence: Mongol invasion of 
Rus' (is known as the Tatar-Mongol Yoke - 13 to 15 century), serfdom, numerous wars (I World War, II World War), and revolutions (1905, 1917). I believe that the best way to close this paper is with a quote that illustrates, more concisely than any analysis could, the complex interaction of folklore traditions, literary models, and historical context of the Russian conception of stupidity:

Такой была народная мечта - без тяжёлого труда получить то, что хочешь [...] Почему герой в сказках получает всё это? [...] Оказывается, что Иванушка совсем не дурачок. Он только притворяется глупым, чтобы потом стать победителем [...] приобрести богатство, счастье, красавицу-невесту. Корни такого характера, видимо, находятся в российской истории: владычество татар, войны, революции, крепостное право. Чтобы выжить в этих условиях, обмануть судьбу, надо было быть осмотрительным, терпеливым, больше надеяться на чудо, чем на себя. Народная мудрость советовала быть осторожным, экономно тратить силы. Так сформировался характер человека, который не всегда любил трудиться (работал на хозяина), мог терпеть трудности, но вместе с тем не помнил зла, был щедрым и гостеприимным.

The people's dream was getting what you want without working hard [...] Why does a fairy tale hero get everything? [...] It turns out that Ivanushka is not a fool at all. He only pretends to be stupid, then to become a winner [...] to acquire wealth, happiness, a beautiful bride. The roots of this character, apparently, are in Russian history: the rule of the MongolTatars, wars, revolutions, serfdom. To survive under these conditions, outwit fate, it was required to be cautious, prudent patient, rely more on miracles than on yourself. Folk wisdom advised to be cautious, save and economize energy. In this way a man's character was formed, it was a man who did not always like to work (he worked for the owner), he could endure difficulties, but at the same time he did not remember the bad things, was generous and hospitable. (Belianko and Trushina, 1996 trans. mine).

\section{LIST OF REFERENCES}

Abdarahmanova I.E. (2010) Sovershenstvovanie russkoi rechi inostrannykh studentov na osnove vospriiatiia rossiiskoi audiovizual'noi kul'tury: Avtoref. dis.... d-ra ped. nauk. [Improving Russian Speech based on the Perception of the Russian Audiovisual Culture: Doctoral Thesis Abstract]. Moskva: Moscow State Pedagogical University.

Ajibola A.F. (2014) "Integrating Folktales in the Teaching of German. A Practical Approach". International Journal of Humanities and Social Science, Vol. 4, No. 11 (1); September 2014, pp. 246-51.

Arysheva T.M. (2014) Russkaiia narodnaia skazka na zaniatiiah po russkomu iazuku kak inostrannomu. [Russian folk tale in Russian as a foreign language lesson]. www.kgau.ru/new/all/konferenc/konferenc/2014/g17.pdf. [23.02.2019].

Barsukova-Sergeieva O.M. (2013) "Russskaia narodnaia skazka kak instrument formirovaniia kommunikativnoi kompetenzii inostrannyh uchaschihs'a”. [Russian folk tale as a tool of 
foreign students' communicative competence formation]. Russkii iazyk za rubezhom. № 4 , pp. 28-35.

Batyi Irina. (2008) "Chego pozhelat' Duraku" [What to wish for a Fool] http://www.foru.ru/slovo.15450.8.html Moskva, RPF-university.[11.04.2019].

Belianko O.E., and Trushina L.B. (1996) Russkiie s pervogo vzgl'ada. Chto prin'ato i chto ne prin'ato u russkih. [Russians at first glance. The do`s and dont's in Russia: A book on reading and communication skills training]. Moscow.

Bordovskaia A.V. (2005) Mesto skazki kak nazional'no-prezedentnogo fenomena na urokah RKI. [The place of a fairy tale as a national-precedent phenomenon in RFL lessons. Rusistics and modernity - Proceedings of the VII International Scientific and Practical Conference]. The Herzen State Pedagogical University. pp. 72-5.

Dal' V.I. (2006) Poslovizy russkogo naroda. [Proverbs of the Russian people]. Moskva: EKSMO.

Fliantikova E.V. (2016) "Ispol'zovaniie russkih narodnyh skazok na urokah RKI”. [The use of Russian folk tale in Russian as a foreign language lesson]. Problemy prepodavaniia filologicheskih disziplin inostrannym uchaschims'a: sbornik materialov IV mezhdunarodnoi nauchno-prekticheskoi konferenzii. Voronezh. pp. 140-45.

Goscilo Helena (2005) Folkloric Fairy Tales. In: Politicizing Magic. An Anthology of Russian and Soviet Fairy Tales. Eds. Marina Balina, Helena Goscilo, and Mark Lipovetsky. Evanston, Illinois: Northwestern University Press. pp. 5-23.

Igoshina O.A. (2003) Lingvokul'turologicheskii analiz fol'klornogo teksta pri obuchenii russkomu iazyku nemetskoiazychnykh studentov: dis.... kand. ped. Nauk [A CulturalLinguistic Analysis of Folklore Texts in Learning Russian by German-speaking Students: Ph. D. Thesis]. St. Petersburg.

Krivonos E.A. (2010) Ispol'zovanie mul'tiplikatsionnykh fil'mov na uroke RKI [The Use of Animated Films in the Lessons of Russian as a Foreign Language]. Mezhdunarodnye otnosheniia: istoriia, teoriia, praktika: materially I nauch.-prakt. konf. molodykh uchenykh fak. Mezhdunar. Otnoshenii BGU. Minsk, BGU.

Lipovetsky Mark (2005) Fairy Tales in Critique of Soviet Culture. In: Politicizing Magic. An Anthology of Russian and Soviet Fairy Tales. Eds. Marina Balina, Helena Goscilo, and Mark Lipovetsky. Evanston, Illinois: Northwestern University Press. pp. 233-251.

Lwin S.M. (2015) "Using Folktales for Language Teaching". The English Teacher, XLIV (2), pp. 74-83.

Matveenko V. (2013) "Ispolzovaniye russkih narodnyh skazok v prozesse obucheniya studentov-philologov RKI s uchiotom sovremennyh tehnologii”. [The use of Russian folk tales in the process of teaching of Russian as a foreign language for philologists taking into account modern technologies]. Vestnik RUDN, seriia 'Ruskii I inostranyie iazyki I metodika ih prepodavaniia', Moskva, RPF-university, \# 4, pp. 72-82.

Merrill J. (2016) Russian Folktales: A Reader for Students of Russian. Indianapolis: Hackett Publishing Company.

Nhung Pham Thi Hong (2016) "Folktale as a Valuable Rich Cultural and Linguistic Resource to Teach a Foreign Language to Young Learners". International Journal of Education, Culture, and Society. Vol. 1. No. 1. pp. 23-8. 
Prastiwi Y. Folktales as a medium of teaching English: two primary schools in Solo, Indonesia. Deakin University. dro.deakin.edu.au/eserv/DU: 30082775/prastiwi-folktales-2015A.pdf. [29.06.2019].

Schwabe Christa C. Jones Claudia (2016) New Approaches to Teaching Folk and Fairy Tales, Urban Institute, University Press of Colorado. http://www.jstor.org/stable/j.ctt1f2qr02.[14.09.2019].

Shilko T. (2012) "Narodnaia skazka v prozesse obucheniia russkomu iazuku kak inostrannomu". [The Russian folk tale in the process of teaching of Russian as a foreign language]. Teoriia i praktika prepodavaniia russkogo iazyka kak inostrannogo. Vorzlav, pp. 169-78.

Vasilii (2005) Before the Cock Crows Thrice. In: Politicizing Magic. An Anthology of Russian and Soviet Fairy Tales. Eds. Marina Balina, Helena Goscilo, and Mark Lipovetsky. Evanston, Illinois: Northwestern University Press. pp. 345-81.

Sinyavsky A. (2007) Ivan the Fool. Russian folk Belief. A Cultural History. Moskva: Glas.

Sulima N.A. (2008) "Skazka o Ivane Zareviche I ob odnom iz iego podvigov" [The tale of Ivan Tsarevich and one of his feats]. 'Молодой', 2008. http://www.molodoi-gazeta.ru/article3447.html [07.05.2019].

Taylor E. K. (2006) Using Folktales: Cambridge Handbooks for Language Teachers. Cambridge: Cambridge University Press.

Tolstoy L. (1962) The Tale of Ivan the Fool and his two brothers, Semyon the Soldier and Taras the Big-Belly, and of his sister Malyana the Mute, and of the Old Devil and the three Imps. In Tolstoy, L. Fables and Fairy Tales. New York: A Signet Classic, pp. 102-139.

Trubetskoi E.N. (1995) "Inoie zarstvo" i iego iskateli v russkoi narodnoi skazke. [Far Far Away Kingdom and its seekers in a Russian folk tale]. Moskva: Kanon.

Trygub I.S. (2006) Lingvometodicheskii potensial narodnykh skazok v obuchenii russkomu iazyku kak inostrannomu mladshikh shkol'nikov: avtoref. dis....kand. ped. nauk. [Cultural-Linguistic Potential of Folk Fairy Tales in Learning Russian as a Foreign Language for Junior Schoolchildren: Ph. D. Thesis Abstract]. Moskva.

Vorkachev S.G. (2017) 'Iazyk i etnicheskaiia mental'nost': Ivan-durak kak lingvokulturnyi geroi". [The language and the ethnic mentality: Ivan the Fool as a linguacultural hero]. Russkii iazyk v polikul'turnom mire. Pervyi Mezhdunarodnyi Simpozium. 8-12 June 2017. Issue II. Simferopol', pp. 14-20.

Zaharenko I.V. (2004) "Ivan-durak". [Ivan the Fool]. Russkoie kulturnoie prostranstvo: lingvokul'turologicheskii slovar'. Moskva: Gnozis, pp. 198-200.

\section{For citation:}

Roitberg, N. V. (2020) THE MYTH OF RUSSIAN STUPIDITY IN RFL LESSONS. International Scientific-Pedagogical Organization of Philologists "WEST-EAST " (ISPOP). Scientific Journal WEST-EAST. Vol 3 N1 (March, 2020). pp. 11-16. doi: 


\section{Для цитирования:}

Ройтберг, Н. В. (2020) Миф о русской глупости на уроках РКИ // International ScientificPedagogical Organization of Philologists “WEST-EAST” (ISPOP). Scientific Journal WESTEAST. Vol 3N1 (March, 2020). C. 11-16. doi:

Information about the author: Natalia V. Roitberg - $\mathrm{PhD}$ in Philology, lecturer, foreign language teacher, University of Haifa (Israel)

e-mail: roitbergnatalia@gmail.com

Сведения об авторе: Наталья Владимировна Ройтберг - кандидат филологических наук, лектор, преподаватель иностранного языка, Хайфский Университет (Израиль) e-mail: roitbergnatalia@gmail.com

Manuscript received: 11/15/2019

Accepted for publication: $01 / 14 / 2020$

Рукопись получена: 11/15/2019

Принята к печати: 01/14/2020 